\title{
Effects of Grazing Intensity on the Regeneration of Woody Species in an Oak Woodland
}

\author{
Aimilia LEMPESI, Alexia ELEFTHERIADOU, Zacharoula DELIVASI, \\ Aikaterini PSYLLIDOU, Georgios KORAKIS, \\ Apostolos P. KYRIAZOPOULOS*
}

\begin{abstract}
Democritus University of Thrace, Department of Forestry and Management of the Environment and Natural Resources, 193 Pantazidou str., 68200Orestiada,Greece; lembesi.aimilia@gmail.com; alexiaelefth@gmail.com; xaroula_deli@hotmail.com;LamarinaPsil@hotmail.com; gkorakis@fmenr.duth.gr; apkyriaz@fmenr.duth.gr (*correspondingauthor)
\end{abstract}

\begin{abstract}
In the Mediterranean regions, oak forests are commonly used for livestock grazing. However, it is well documented that livestock grazing is an essential factor that can affect the success of natural regeneration of oak and other woody species of the understorey. Consequently, it influences the composition and structure of oak woodlands. The main objective of the present study was to examine the effects of grazing intensity on characteristics of oak seedlings establishment (density, height, number of leaves) and on the diversity of the woody species seedlings. The research was conducted in open canopy Quercus frainetto woodland, grazed by a herd of 500 goats for eight months per year, located in Evros region, north-eastern Greece. The distance from a goat corral was used to represent relative grazing intensity. In May 2016, vegetation measurements were made along transects placed at 50,150,300, 600 and $1200 \mathrm{~m}$ from the goat corral, running perpendicular to four replicates. According to the results, increased grazing intensity significantly reduced the density, the plant height and the number of leaves of Quercus frainetto seedlings. Grazing intensity did not affect significantly diversity, evenness and dominance indices for the woody species seedlings. However, heavy grazing reduced species richness and the Chaol index.
\end{abstract}

Keywords: goat grazing, Quercus frainetto, seedlings establishment, silvopastoral system, species diversity

\section{Introduction}

It is well substantiated that oak woodlands have essential ecological and socioeconomic importance in the Mediterranean region (López-Sánchez et al., 2014). They are among the major components of biodiversity hot spots (Eichhorn et al., 2006), while they support rural population by providing a variety of wood products and forage for livestock (Lopez-Sanchez et al., 2014). Oak woodlands and shrublands comprise the most widespread vegetation type in Greece. Deciduous oaks cover approximately $23 \%$ of the country's high forest (1.5 million ha) and specific oak woods are traditionally used for livestock grazing (Anonymous, 1992; Koutsidou et al., 2008; Manousidis et al., 2016a).

Woodland grazing is an important part of the European cultural and ecological heritage (Hartel and Plieninger, 2014). Although traditional forest grazing has been reduced in many parts of Europe, it is still practiced in the Mediterranean region (Humphrey et al., 1998) as small ruminants are able to profit from this type of vegetation (Varela and Robles-Cruz, 2016). Oak woodlands and shrublands are important forage sources especially for goats as they prefer woody species more than herbaceous ones and their diet consists mainly of lignified species (Manousidis et al., 2016b).

Grazing in woodlands has been debated in Europe and elsewhere as grazing herbivores are considered to pose a serious threat on the biodiversity, regenerative capability of woody species and economic value of multi-purpose forests. Plieninger (2007) reported that livestock grazing has enhanced biodiversity and reduced wild fire risk, but may endanger the long-term stability of woodland ecosystems. Grazing includes not only defoliation by animals, but it is also associated with disturbances such as animal trampling, soil compaction and mineralization by deposition of urine and feces (Alados et al., 2004) which in turn determines the patterns of vegetation in the Mediterranean ecosystems (Carmel and Kadmon, 1999). Forest grazing has been reported to cause tree damage through trampling and browsing (Mayer et al., 2006; Vandenberghe et al., 2007) and loss of species richness and diversity (Fleischner, 1994). Moreover, forest grazing is widely considered as negative to natural regeneration of broadleaved tree species in particular 
598

(Van Ijssel, 1990). However, there are findings suggesting that despite livestock impacts to some saplings, damage levels were insufficient to alter tree regeneration (Buffum $e t$ al., 2009; Kaufmann et al., 2014). McCreary and George (2005) reported that the presence or absence of livestock was not sufficient to explain the pattern of oak regeneration. Forest grazing can enhance tree growth by reducing the biomass of herbaceous and shrubby vegetation that outcompete tree seedlings (Darabant et al., 2007). Grazing has also been reported to promote biodiversity (Mountford and Peterken, 2003; Mosquera-Losada et al., 2009). Lempesi $e t$ al. (2013) results in a grazed oak woodland in northern Greece confirmed the moderate grazing hypothesis (Noy Meyer, 1995; Tilman, 1997) that light and moderate grazing results in an increase of biodiversity. Thus, managed woodland grazing systems are increasingly recognised as being beneficial to woodland biodiversity (McEvoy et al., 2005).

It is well documented that the effects of livestock grazing on the vegetation of the Mediterranean ecosystems are dependent on grazing intensity (Milchunas and Lauenroth, 1993; Montalvo et al., 1993; Osem et al., 2002). Thus, the objective of the present study was to examine the effects of grazing intensity on the characteristics of oak seedlings establishment (density, height, number of leaves) and on the diversity of the woody species seedlings.

\section{Materials and Methods}

The research was conducted in the area of Pentalofos, which is located in Evros region, NE Greece (Fig. 1). The oak forest of Pentalofos occupies a total area of 10200 ha. It is mainly used by the local population for firewood production and for livestock grazing. Several species of deciduous oaks consist the forest canopy comprising Quercus frainetto, which is dominant, while other species such as Q. petraea, Q. pubescens and Q. cerris are less common. Other woody species, more or less frequently found, include Carpinus orientalis, Fraxinus ornus, Juniperus oxycedrus, Cornus mas, Tilia tomentosa, Phillyrea latifolia and Acer monspessulanum. The climate of the area is classified as sub-Mediterranean, with cold, moist winters and warm, dry summers. The average maximum temperature is $30.5^{\circ} \mathrm{C}$ in July and the average minimum temperature is $-7.0{ }^{\circ} \mathrm{C}$ in January. The mean annual precipitation is $539.5 \mathrm{~mm}$. The study area is grazed mainly by a herd of 500 Greek local breed goats for eight months per year.

The distance from a goat corral was used to represent relative grazing intensity. In May 2016, vegetation measurements were taken within quadrats of $1 \mathrm{~m}^{2}$ that placed along transects of $20 \mathrm{~m}$ long. The transects were placed at 50,150, 300, 600 and $1200 \mathrm{~m}$ from the goat corral, running perpendicular to four replicates. These distances stand for very heavy, heavy, moderate, light and very light grazing, respectively. The number of woody species, the density of oak seedlings, the height of each seedling and the number of leaves per seedling were measured in each quadrat. Additionally, species richness, species diversity, evenness and dominance were determined

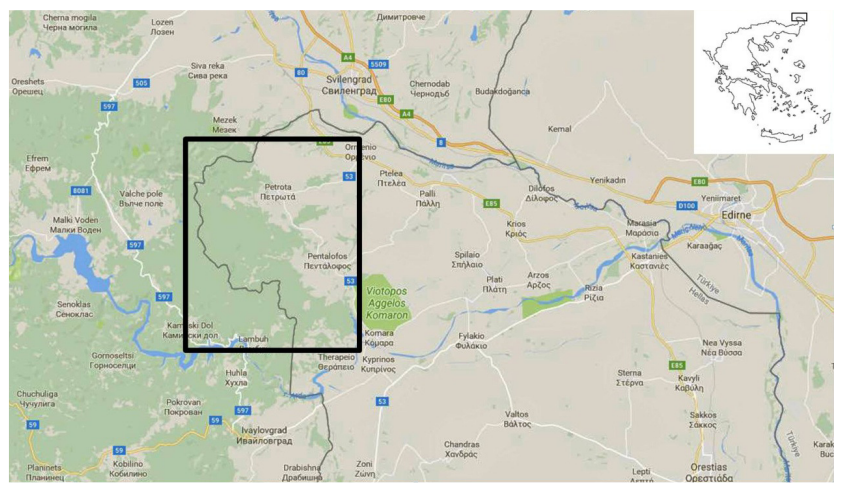

Fig. 1. Location map of study area

for the woody seedlings by the following indices: The Shannon-Wiener evenness index $(E)$, the Simpson diversity index $(C)$, the Chaol index $(S)$, and the Berger-Parker dominance index $(D)$. The formulae of the indices are given below (Henderson, 2003):

$$
\begin{aligned}
& \mathrm{E}=\mathrm{H} / \log _{2} \mathrm{~S} \\
& \mathrm{D}=1 / \mathrm{C} \text { where } C=1-\sum_{i}^{S_{\text {obs }}} p_{i}{ }^{2} \\
& \mathrm{~d}=\mathrm{N}_{\max } / \mathrm{N}_{\mathrm{T}}
\end{aligned}
$$

where $S$ is the maximum recorded number of taxa, $p_{i}$ is the proportional abundance of the i-th taxa, $N_{\max }$ is the number of records of the dominant taxon and $N_{T}$ is the total number of records.

$\mathrm{S}_{\text {Chaol }}=\mathrm{S}_{\text {obs }}+\mathrm{n}_{1}^{2} / 2 \mathrm{n}_{2}$

where $S_{o b s}$ is the number of observed species, $n_{1}$ is the number of singletons (species captured once), and $n_{2}$ is the number of doubletons (species captured twice). Floristic diversity indices were calculated using the PASTPAlaeontological STatistics program (Hammer et al., 2001).

One-way ANOVA was used to analyse the effect of grazing intensity on the characteristics of oak seedlings (density, height, number of leaves) and on the diversity indices of the woody species seedlings. The LSD at the 0.05 probability level was used to detect the differences among means (Steel and Torrie, 1980). The obtained data were analysed using the SPSS statistical software v. 17.0 (SPSS Inc. Chicago, IL, USA).

Data were subjected to simple linear regression analyses with the distance from the corral as the independent variable and the characteristics of oak seedlings (density, height, number of leaves) as the dependent variables. The choice of the best-fit equation was based on the coefficient of determination.

\section{Results and Discussion}

Deciduous woody species, and especially oak, are highly preferred by goats, and comprise a great proportion of their diet whenever they are available (Papachristou and Nastis, 1996; Manousidis et al., 2016b). However, although grazing removes leaf tissue, in most cases, it will not harm the growing point that produces the leaves (Trlica, 1999). Grazing intensity significantly affected oak seedlings density, their height and the number of leaves (Table 1). Oak seedling density and the number of leaves per seedling 
were significantly higher under very light grazing, while height was significantly increased under light grazing intensity followed by the very light one. Generally the values of all the measured characteristics of oak seedlings were decreased as grazing intensity increased. Regression analyses (Table 2) revealed a significant linear relationship between grazing intensity and seedling density $\left(\mathrm{R}^{2}=0.96\right)$ and the number of leaves per oak seedling $\left(R^{2}=0.81\right)$. However, coefficient of determination was lower $\left(\mathrm{R}^{2}=0.47\right)$ for seedling height, indicated that the variation in this trait could be explained by other factors besides grazing intensity. The results of the present study are suggesting that survival and growth of Quercus seedlings in heavily grazed areas are significantly limited. These results are in agreement with those of Carmona et al. (2013) who observed an important effect of grazing regime on the height of oak juveniles. Additionally, Al-Rowaily et al. (2015) found that livestock exclusion significantly increased density of shrubs and trees. Moreover, Smit et al. (2006) reported that livestock grazing can directly destroys seeds and seedlings, thus reducing natural regeneration. Browsing of oak seems to be an essential factor driving regeneration rate, although other environmental factors have been reported to be important too (López-Sánchez et al., 2014). Moreover, long-term heavy grazing can indirectly affects oak recruitment by increasing soil compaction and reducing organic matter (Welker and Menke, 1987).

Overall, seedlings of eight woody plant species were recorded. Grazing intensity did not affect significantly Simpson diversity index (C), Shannon-Wiener evenness index (E) and Berger Parker dominance index (D), of the woody seedlings (Table 3). Significantly lower N (Number of species) and Chaol index $(S)$ was recorded at the distances close to the goat corral (Table 3). The Chaol estimate richness by adding a correction factor to the observed number of species (Hughes et al., 2001).

Grazing is a major factor controlling species composition and diversity (McNaughton, 1983; Ren et al., 2012). Alados et al. (2004) found that the number of species declined significantly with grazing pressure. In contrast, Pizzio et al. (2016) reported that the range of stocking rates had no effect on species richness, but reduced diversity through the effect on evenness. These differentiated results can be attributed to the different type of ecosystem and to different type of grazer. Lempesi $e t a l$. (2013) found that goats browsing affected species diversity of the woody vegetation layer but had minimum impact on the herbaceous vegetation layer.

Species richness can serve as a comprehensible index of community structure (Gotelli and Colwell, 2010). Vrahnakis et al. (2014) have reported that plant diversity of valonia oak silvopastoral woodlands is determined mostly by management factors such as grazing intensity. Grazing in oak woodlands can combat shrub encroachment which is negatively correlated with plant species richness and diversity of such ecosystems in the Mediterranean region (Alados et al., 2004). The results of the present study indicated that moderate grazing can control woody species expansion in oak woodland, fact that can benefit the function of this ecosystem and promotes some of the ecosystem services provided.

Table 1. Effect of goat grazing intensity on seedling density, seedling height and number of leaves per Quercus frainetto seedling

\begin{tabular}{|c|c|c|c|}
\hline $\begin{array}{l}\text { Distance from the corral } \\
\qquad(\mathrm{m})\end{array}$ & $\begin{array}{l}\text { D - seedling density } \\
\left(\text { no plants } / \mathrm{m}^{2}\right)\end{array}$ & $\begin{array}{l}\text { H - seedling height } \\
(\mathrm{cm})\end{array}$ & $\begin{array}{c}\text { Number of leaves / } \\
\text { seedling }\end{array}$ \\
\hline 50 & $6.2 \mathrm{~b}$ & $4.8 \mathrm{bc}$ & $2.1 \mathrm{~b}$ \\
\hline 150 & $4.5 \mathrm{~b}$ & $10.5 \mathrm{ab}$ & $4.9 \mathrm{~b}$ \\
\hline 300 & $2.5 \mathrm{~b}$ & $8.7 \mathrm{~b}$ & $4.0 \mathrm{~b}$ \\
\hline 600 & $15.7 \mathrm{ab}$ & $19.7 \mathrm{a}$ & $4.1 \mathrm{~b}$ \\
\hline 1200 & $30.0 \mathrm{a}$ & $15.2 \mathrm{ab}$ & $9.8 \mathrm{a}$ \\
\hline $\mathrm{LSD}_{0.05}$ & 17.6 & 9.4 & 3.93 \\
\hline
\end{tabular}

Note: Means in the same column followed by the same letter are not significantly different (LSD test, P $\leq 0.05$ )

Table 2. Prediction models for seedling density, seedling height and number of leaves per Quercus frainetto seedling as a function of the goat grazing intensity

\begin{tabular}{ccc}
\hline Oak characteristics & Simple linear regression equation & $\mathrm{R}^{2}$ \\
\hline Seedling density & $0.0266 \mathrm{X}-1.7826$ & 0.96 \\
Seedling height & $0.0086 \mathrm{X}+7.8128$ & 0.47 \\
Number of leaves per seedling & $0.0056 \mathrm{X}+2.4004$ & 0.81 \\
\hline
\end{tabular}

Note: Independent variable $(\mathrm{X})=$ distance from the goat corral

Table 3. Number of species (N), Simpson diversity index (C), Shannon-Wiener evenness index (E), Berger Parker dominance index (D) and Chaol (S) for the woody seedlings at the different distances from the goat corral

\begin{tabular}{|c|c|c|c|c|c|}
\hline $\begin{array}{c}\text { Distance from the } \\
\text { corral }(\mathrm{m})\end{array}$ & $\mathrm{N}$ & $\mathrm{C}$ & $\mathrm{E}$ & $\mathrm{D}$ & $S$ \\
\hline 50 & $1.25 \mathrm{bc}$ & $1.00 \mathrm{a}$ & $0.67 \mathrm{a}$ & $0.64 \mathrm{a}$ & $1.25 \mathrm{ab}$ \\
\hline 150 & $0.75 \mathrm{c}$ & $0.75 a$ & $0.75 a$ & $0.75 \mathrm{a}$ & $0.75 \mathrm{~b}$ \\
\hline 300 & $1.50 \mathrm{abc}$ & $1.38 \mathrm{a}$ & $0.96 a$ & $0.84 \mathrm{a}$ & $1.50 \mathrm{ab}$ \\
\hline 600 & $2.00 \mathrm{ab}$ & $1.42 \mathrm{a}$ & $0.80 \mathrm{a}$ & $0.85 \mathrm{a}$ & $2.25 \mathrm{a}$ \\
\hline 1200 & $2.25 \mathrm{a}$ & $1.39 \mathrm{a}$ & $0.72 \mathrm{a}$ & $0.83 \mathrm{a}$ & $2.25 \mathrm{a}$ \\
\hline $\mathrm{LSD}_{0.05}$ & 0.89 & NS & NS & NS & 1.23 \\
\hline
\end{tabular}




\section{Conclusions}

Increased grazing intensity significantly reduced oak seedling density, their height and the number of leaves per seedling. These results strongly suggest that heavy goat grazing significantly reduced the regeneration success and survival of oak seedlings. However, goats controlled other woody species encroachment as indicated by the reduced number of species recorded under high grazing intensity, fact that may enhances biodiversity and benefits a number of ecosystem services. Sustainable grazing management practices have to be applied in order to maintain Mediterranean oak woodlands.

\section{References}

Alados L, ElAich A, Papanastasis VP, Ozbek H, Navarro T, Freitas H, Vrahnakis M, Larrosi D, Cabezudo B (2004). Change in plant spatial patterns and diversity along the successional gradient of Mediterranean grazingecosystems. Ecological Modelling 180:523-535.

Al-Rowaily SL, El-Bana MI, Al-Bakre DA, Assaeed AM, Hegazy AK, Ali $\mathrm{MB}$ (2015). Effects of open grazing and livestock exclusion on floristic composition and diversity in natural ecosystem of Western Saudi Arabia. SaudiJournal of Biological Sciences 22(4):430-437.

Anonymous (1992). Results of the first national forest inventory of Greece. Hellenic Ministry of Agriculture, General Secretariat of Forests and Natural Environment. Athens $134 \mathrm{p}$ (in Greek).

Buffum B, Gratzer G, Tenzin Y (2009). Forest grazing and natural regeneration in a late successional broadleaved community forest in Bhutan. Mountain Research and Development 29(1):30-35.

Carmel Y, Kadmon R (1999). Effects of grazing and topography on longterm vegetation changes in a Mediterranean ecosystem in Israel. Plant Ecology 145(2):243-254.

Carmona CP, Azcárate FM, Oteros-Rozas E, González JA, Peco B (2013). Assessing the effects of seasonal grazing on holm oak regeneration: implications for the conservation of Mediterranean dehesas. Biological Conservation 159:240-247.

Darabant A, Rai PB, Kenzin K, Roder W, Gratzer G (2007). Cattle grazing facilitates tree regeneration in a conifer forest with palatable bamboo understory. Forest Ecology and Management 252:73-83.

Eichhorn M, Paris P, Herzog F, Incoll L, Liagre F (2006). Silvoarable systems in Europe - past, present and future prospects. Agroforestry Systems 67:29-50.

Fleischner TL (1994). Ecological costs of livestock grazing in western North America. Conservation Biology 8:629-644.

Gotelli NJ, Colwell RK (2010). Estimating species richness. Biological Diversity: Frontiers in Measurement and Assessment. Oxford University Press 4:39-54.

Hammer O, Harper DAT, Ryan PD (2001). PAST: Paleontological statistics software package for education and data analysis. Palaeontologia Electronica 4:1-9.

Hartel T, Plieninger T (2014). European wood-pastures in transition: A social-ecological approach. Earthscan Publications Ltd, Abingdon, UK.

Henderson PA (2003). Practical methods in ecology. Blackwell Science Ltd, Oxford, UK.
Hughes JB, Hellmann JJ, Ricketts TH, Bohannan BJM (2001). Counting the uncountable: Statistical approaches to estimating microbial diversity. Applied and Environmental Microbiology 67(10):4399-4406.

Humphrey J, Gill R, Claridge J (1998). Grazing as a management tool in European forest ecosystems. Forestry Commission Technical Paper 25, Forestry Commission, Edinburgh.

Kaufmann J, Bork EW, Alexander MJ, Blenis PV (2014). Effects of openrange cattle grazing on deciduous tree regeneration, damage, and mortality following patch logging. Canadian Journal of Forest Research 44(7):777-783.

Koutsidou E, Chalios K, Margaris NS (2008). The impact of grazing in (Quercusithaburensis subsp. macrolepis) forest regeneration in W.Lesvos, Greece. Range Science and protected areas. Proceedings of the 6th Panhellenic Rangeland Congress in Leonidio Arcadia Peloponnesus pp 69-75.

Lempesi A, Kyriazopoulos AP, Orfanoudakis M, Korakis G (2013). Soil properties and plant community changes along a goat grazing intensity gradient in an open canopy oak forest. Notulae Botanicae Horti AgrobotaniciCluj-Napoca41(2):567-575.

López-Sánchez A, Schroeder J, Roig S, Sobral M, Dirzo R (2014) Effects of cattle management on oak regeneration in northern Californian Mediterranean oak woodlands. PLoSONE9(8): e105472

Manousidis T, Malesios C, Kyriazopoulos AP, Parissi ZM, Abraham EM, Abas Z (2016a). A modeling approach for estimating seasonal dietary preferences of goats in a Mediterranean Quercus frainetto - Juniperus oxycedrus woodland. Applied Animal Behaviour Science 177:25-33.

Manousidis T, Kyriazopoulos AP, Parissi ZM, Abraham EM, Korakis G, Abas Z (2016b). Grazing behavior, forage selection and diet composition of goats in a Mediterranean woody rangeland. Small Ruminant Research 145:142-153.

Mayer AC, Stockli V, Konold W, Kreuzer M (2006). Influence of cattle stocking rate on browsing of Norway spruce in subalpine wood pastures. Agroforestry Systems 66:143-149.

McCreary DD, George MR (2005). Managed grazing and seedling shelters enhance oak regeneration on rangelands. California Agriculture 59(4):217-222

McEvoy PM, McAdam JH, Mosquera-Losada MR, Rigueiro-Rodriguez A (2005). Tree regeneration and sapling damage of pedunculate oak Quercus robur in a grazed forest in Galicia, NW Spain: a comparison of continuous and rotational grazing systems. Agroforestry Systems 66:8592.

McNaughton SJ (1983). Serengeti grassland ecology: the role of composite environmental factors and contingency in community organization. Ecological Monographs 53:291-320.

Milchaunas DG, Lauenroth WK (1993). Quantitative effects of grazing on vegetation and soils over a global range of environments. Ecological Monographs 63:327-366.

Montalvo J, Casado MA, Levassor C, Pineda FD (1993). Species diversity patterns in Mediterranean grasslands. Journal of Vegetation Science 4:213-222.

Mosquera-Losada MR, Rodríguez-Barreira S, López-Díaz ML, FernándezNúnez E, Rigueiro-Rodríguez A (2009). Biodiversity and silvopastoral system use change in very acid soils. Agriculture, Ecosystems and 


\section{Environment 131:315-324.}

Mountford EP, Peterken GF (2003). Long-term change and implications for the management of wood-pastures: Experience over 40 years from Denny Wood, New Forest. Forestry 76:19-43.

Noy-Meir I (1995). Interactive effects of fire and grazing on structure and diversity of Mediterranean grasslands. Journal of Vegetation Science 6:701-710.

Osem Y, Petrovolotsky A, Kigel J (2002). Grazing effect on diversity of annual plant communities in a semi-arid rangeland: interactions with small-scale spatial and temporal variation in primary productivity. Journal of Ecology 90:936-946.

Papachristou TG, Nastis AS (1996). Influence of deciduous broadleaved woody species in goat nutrition during the dry season in northern Greece. Small Ruminant Research 20:15-22.

Pizzio R, Herrero-Jauregui Cr, Pizzio M, Oesterheld M (2016). Impact of stocking rate on species diversity and composition of a subtropical grassland in Argentina. Applied Vegetation Science 19:454461.

Plieninger T (2007). Compatibility of livestock grazing with stand regeneration in Mediterranean holm oak parklands. Journal for Nature Conservation 15:1-9.

Ren H, Schonbach P, Wan H, Gierus M, Taube F (2012) Effects of grazing intensity and environmental factors on species composition and diversity in typical steppe of Inner Mongolia, China. PLOS ONE 7:12.

Smit C, Gusberti M, Müller-Schärer H (2006). Safe for Saplings; Safe for Seeds? ForestEcology and Management 237:471-477.
Steel RGD, Torrie JH (1980). Principles and procedures of statistics, 2nd edition. McGraw-Hill, New York.

Tilman D (1997). Community invasibility, recruitment limitation and grassland biodiversity. Ecology 78:81-92.

Trlica MJ (1999). Grass Growth and Response to Grazing. Natural Resources Series ColoradoState University 6:108.

Van Ijssel W (1990). The effect of grazing and seedbed type on forest regeneration under two silvicultural systems in a mixed broadleaf forest, Gedu. Tsenden 3(1):32-44.

Vandenberghe C, Francois F, Moravie MA, Gadallah F, Buttler A (2007). Short-term effects of cattle browsing on tree sapling growth in mountain wooded pastures. PlantEcology 188:253-264.

Varela E, Robles-Cruz AB (2016). Ecosystem services and socio-economic benefits of Mediterranean grasslands. Options Méditerranéennes (114):13-27.

Vrahnakis MS, Fotiadis G, Pantera A, Papadopoulos A, Papanastasis VP (2014). Floristic diversity of valonia oak silvopastoral woodlands in Greece. Agroforestry Systems 88:877-893.

Welker JM and Menke JW (1987). Quercus douglasii seedling water relations in mesic and grazing-induced xeric environments. In: Hanks RJ, Gardner WR, Halbertsma J, Przybyla C (Eds). Proceedings of International Conference on Measurement of Soil and Plant Water Status. Springer, Logan, Utah pp 229-234. 